HISTORIA: Jurnal Pendidik dan Peneliti Sejarah, 3(1), 1-10, DOI: 10.17509/historia.v3i1.17107.

Available online at HISTORIA; Jurnal Pendidik dan Peneliti Sejarah
Journal homepage: https://ejournal.upi.edu/index.php/historia

\title{
SEBARAN DAN DOMINASI PEMIKIR ILMU PENDIDIKAN DI LEMBAGA PENDIDIKAN TENAGA KEPENDIDIKAN (LPTK) 1954-1999
}

\author{
Edi Subkhan \\ Jurusan Kurikulum dan Teknologi Pendidikan, \\ Fakultas Ilmu Pendidikan, Universitas Negeri Semarang (UNNES) \\ edi.subkhan@mail.unnes.ac.id
}

To cite this article: Subkhan, E. (2020). Sebaran dan dominasi pemikir ilmu pendidikan di lembaga pendidikan tenaga kependidikan (LPTK) 1954-1999. HISTORIA: Jurnal Pendidik dan Peneliti Sejarah, 3(1), 1-10. https://doi.org/10.17509/ historia.v3i1.17107

Naskah diterima : 11 Mei 2019, Naskah direvisi : 14 November 2019, Naskah disetujui : 27 November 2019

\begin{abstract}
This article tracing the existence of the pedagogic thinkers and their works in several teacher colleges in Indonesia in the period of 1950 to the late of 1990, among others in Teacher Training Institute and Pedagogy (IKIP) in Yogyakarta, Bandung, Jakarta, Semarang, Malang, Surabaya, Padang, and Ujung Pandang. This research used qualitative approach by analyzing several classical references on pedagogy and find out that the pedagogic thinkers in IKIP Bandung and Yogyakarta were prominent than others. For examples Imam Barnadib and Noeng Muhadjir from Yogyakarta, and Kartini Kartono, Sikun Pribadi, Redja Mudyahardja, Ngalim Purwanto dan others from Bandung. Several pedagogic thinker from another Teacher College also prominent, but still less productive than pedagogic thinkers from IKIP Bandung and Yogyakarta. It is just Mochtar Buchori and Soegarda Poerbakawatja who could balance the pedagogic thinker's productivity from IKIP Bandung and Yogyakarta.
\end{abstract}

Keywords: Domination; education science; Educational Personnel Education Institute (LPTK); thinking.

\begin{abstract}
Abstrak
Artikel ini menelusuri keberadaan para tokoh pemikir ilmu pendidikan dan karya-karyanya di beberapa LPTK di Indonesia dalam kurun waktu 1950-an hingga 1990-an akhir, antara lain IKIP Yogyakarta, IKIP Bandung, IKIP Jakarta, IKIP Semarang, IKIP Malang, IKIP Surabaya, IKIP Padang, IKIP Ujung Pandang, dan juga beberapa institusi lain. Dengan menggunakan pendekatan penelitian kualitatif melalui penelusuran terhadap referensi-referensi klasik mengenai ilmu pendidikan, terlihat bahwa para penulis ilmu pendidikan di IKIP Bandung dan IKIP Yogya $\neg$ karta sangat menonjol dibanding lainnya. Sebut saja Imam Barnadib dan Noeng Muhadjir dari IKIP Yogyakarta, kemudian Kartini Kartono, Sikun Pribadi, Redja Mudyahardja, Ngalim Purwanto dan lainnya dari IKIP Bandung. Beberapa penulis dari LPTK lain juga cukup diperhitungkan, namun masih kalah produktif dari IKIP Bandung dan IKIP Yogyakarta. Kiranya hanya Mochtar Buchori dan Soegarda Poerbakawatja yang dapat mengimbangi produktivitas dari para penulis ilmu pendidikan IKIP Bandung dan Yogyakarta tersebut.
\end{abstract}

Kata Kunci: Dominasi; ilmu pendidikan; Lembaga Pendidikan Tenaga Kependidikan (LPTK); pemikiran. 


\section{PENDAHULUAN}

Ilmu pendidikan merupakan jantung kehidupan atau ruh bagi praksis pendidikan. Sepanjang para insan pendidik menganggap penting ilmu pendidikan, sepanjang itu pula ilmu pendidikan akan dipelajari, dikaji, dan dikembangkan. Dalam lingkup sistem pendidikan formal di Indonesia, perguruan tinggi pendidik para calon guru atau yang familiar disebut dengan Lembaga Pendidikan Tenaga Kependidikan (LPTK) merupakan kawah tempat mempelajari, mendiskusikan, memperdebatkan, dan mengembangkan ilmu pendidikan. Tak akan dianggap mampu menjadi guru jika mahasiswa belum belajar ilmu pendidikan secara tuntas. Di LPTK itulah, ilmu pendidikan merupakan ruh atau jantung yang harus dihidupkan dan dijaga. Disinilah peran para pemikir pendidikan, khususnya ilmu pendidikan sangat penting, karena merekalah yang dianggap punya otoritas dalam mengembangkan ilmu pendidikan.

Sayang selama ini belum ditemukan kajian khusus yang menelisik keberadaan para tokoh pemikir atau pengkaji ilmu pendidikan di LPTK. Padahal peran mereka sangat penting dalam menyebarkan dan mengembangkan ilmu pendidikan untuk mahasiswa calon guru maupun dunia pendidikan pada umumnya. Barangkali baru H.A.R. Tilaar, guru besar Universitas Negeri Jakarta (UNJ) yang ditelaah pemikirannya karena memang banyak karyanya mengenai pendidikan sebagaimana ditulis oleh (Herlinawati, 2007; Joyo, 2013; Kahfi, 2013; dan Subkhan, 2017). Pemikir pendidikan lain sejauh penelusuran peneliti belum ada yang diulas kiprah dan pemikiran keilmuan pendidikan mereka. Padahal LPTK telah berdiri sejak tahun 1954 di era Presiden Soekarno berkuasa, hingga patut diduga banyak pemikir ilmu pendidikan lahir dari LPTK. Sangat musykil LPTK sebagai lembaga pendidik calon guru tidak memiliki cendekiawan atau pemikir ilmu pendidikan.

Sebenarnya LPTK dan pendidikan keguruan di Indonesia bukan topik yang sepi dari penelitian. Banyak penelitian mengkaji LPTK dan pendidikan keguruan, namun belum ada yang khusus mengidentifikasi keberadaan para tokoh pengkaji atau pemikir ilmu pendidikan di LPTK. Buchori (2009) misalnya meneliti sejarah LPTK, dilihat titik tekan dan karakter LPTK pada tiap periode yang kemudian ia bagi menjadi 4 (empat) fase, yaitu fase rehabilitasi, ekspansi, modernisasi, dan ambivalensi atau keragu-raguan ketika banyak LPTK yang mulanya berstatus institute kemudian berubah menjadi universitas. Demikian pula dengan Suwignyo (2012), ia menelusuri pendidikan calon guru kaitannya dengan pengaruh Amerika Serikat (A.S.), juga pengaruh perpolitikan nasional pada beberapa periode perkembangan LPTK. Selain itu terdapat Supriadi (2003) yang mengedit buku tebal mengenai guru di Indonesia, termasuk pendidikan dan pelatihan yang ditempuh dari masa kolonial hingga reformasi 1998. Walau begitu, data mengenai para tokoh pemikir ilmu pendidikan di LPTK tidak menjadi salah satu bahasan pada beberapa karya tersebut.

Beberapa karya mengenai tokoh pendidikan Indonesia yang beredar lebih banyak mengulas pemikiran para pemikir besar pendidikan di masa kolonial dan di luar lembaga pendidikan calon guru. Misalnya Ki Hadjar Dewantara (Soeratman, 1986), M. Sjafei (Navis, 1996), Tan Malaka (Fridiyanto, 2013), Wahid Hasyim (Zaini, 1998), Willem Iskander (Sularto, 2015). Tokoh-tokoh yang memang berperan besar dalam masa perjuangan Indonesia tersebut sebenarnya juga sudah banyak diulas dalam buku-buku sejarah pendidikan Indonesia, misalnya oleh Purbakawatja (1970). Romo Mangun, rohaniwan cum aktivis pendidikan dan sosial yang banyak berkiprah di masa Orde Baru, juga termasuk pendidik progresif yang sering dikaji, misalnya oleh (Nugroho, 2003). Dengan demikian telaah sederhana dalam bentuk identifikasi nama-nama pemikir dan pengkaji ilmu pendidikan di LPTK belum dilakukan. Jurnal Ilmu Pendidikan (JIP) yang dikelola oleh Universitas Negeri Malang pun belum terdapat ulasan mengenai para tokoh pemikir pendidikan dari LPTK.

Kenyataan tersebut tentu jauh dari kondisi ideal jika memang LPTK punya posisi, peran, dan fungsi penting dalam mengkaji, menyebarkan, dan mengembangkan ilmu pendidikan. Akan repot jika kita hendak mengetahui perkembangan ilmu pendidikan di Indonesia-terutama di lingkungan LPTK-namun tidak memiliki data keberadaan para pemikir ilmu pendidikan di LPTK. Termasuk akan kesulitan juga mengetahui adakah kontribusi para tokoh tersebut terhadap ilmu pendidikan yang sekarang dipelajari oleh mahasiswa di banyak LPTK. Kelangkaan data dan penelitian mengenai tokoh pemikir ilmu pendidikan di LPTK agaknya merupakan buah dari rendahnya kualitas administrasi dan domumentasi LPTK sendiri. Hal tersebut ditunjukkan misalnya oleh kesulitan yang peneliti alami dalam mencari karya-karya pemikir ilmu pendidikan pada beberapa perpustakaan milik LPTK maupun umum. Termasuk juga dipicu rendahnya kesadaran sejarah, bahwa penting mengkaji sejarah pendidikan, termasuk para tokoh, pemikiran, karya, dan gerakannya yang terputus maupun berkesinambungan hingga sekarang.

Berdasarkan pada pertimbangan tersebut, identifikasi keberadaan para tokoh pemikir ilmu 
HISTORIA: Jurnal Pendidik dan Peneliti Sejarah, 3(1), 1-10, DOI: 10.17509/historia.v3i1.17107.

pendidikan dan karyanya sangat penting. Artikel ini mengulas hasil penelitian mengenai keberadaan para tokoh pemikir ilmu pendidikan di LPTK sejak tahun 1954 hingga 1999, yakni sejak awal berdirinya LPTK hingga awal era reformasi. Periode tersebut merupakan periode penting untuk ditelisik upaya-upaya membangun fondasi keilmuan di LPTK, terutama ilmu pendidikan. Peneliti akan menggambarkan sebaran dan dominasi para pemikir ilmu pendidikan pada beberapa LPTK yang dapat peneliti jangkau informasi dan datanya. Penelitian ini merupakan penelitian awal untuk mengidentifikasi dan menelusuri perkembangan ilmu pendidikan di Indonesia, terutama di lembaga-lembaga pendidik calon guru, sekaligus mengisi kekosongan studi mengenai para pemikir ilmu pendidikan di masamasa awal pengembangan LPTK.

\section{METODE}

Penelitian ini menggunakan pendekatan kualitatif agar dapat memperoleh data informasi yang kaya terkait keberadaan para tokoh pendidikan pada beberapa LPTK dan lembaga terkait yang mengkaji serius ilmu pendidikan di masa awal pengembangan LPTK (19541990-an). Beberapa LPTK tersebut yaitu IKIP Jakarta, IKIP Bandung, IKIP Yogyakarta, IKIP Malang, IKIP Surabaya, IKIP Ujung Pandang, IKIP Padang, IKIP Semarang, dan IKIP Surakarta. Pendekatan kualitatif sangat tepat karena memberikan acuan paradigmatik sekaligus panduan metodologis bagaimana mencari informasi yang sifatnya kualitatif, tersebar di banyak tempat, bahkan seringkali tak terprediksi, dan bagaimana mengolahnya. Sebagai penelitian kualitatif, maka penelitian ini tidak bermaksud menghasilkan simpulan baku dan bersifat menggeneralisasi fenomena. Lebih dari itu, penelitian ini lebih berupaya memberikan gambaran keunikan dalam konteks sosial tertentu dan pada masa tertentu saja. Dengan demikian sifatnya kasuistik, unik, dan diharapkan dapat menjadi dasar analisis atau penelitian lebih lanjut pada topik dan tempat yang berbeda.

Penelusuran informasi untuk memperoleh nama para tokoh pemikir pendidikan yang mengkaji ilmu pendidikan di LPTK ini dilaksanakan sejak bulan Mei hingga Oktober 2017. Fokus penelitian adalah pada nama-nama pemikir ilmu pendidikan dan karyakaryanya dalam rentang 1954 hingga 1999 yang berasal dari LPTK tertentu maupun bukan. Para tokoh pemikir pendidikan, khususnya ilmu pendidikan tersebut tentu besar kontribusinya dalam mengembangkan ilmu pendidikan. Dalam hal ini peneliti menelusuri informasi berdasarkan pada referensi-referensi yang membahas ilmu pendidikan yang terbit sejak tahun 1950-an hingga penelitian ini dilakukan (2017). Upaya untuk meningkatkan akurasi dan keterpercayaan informasi penelitian ini dilakukan dengan menggunakan teknik Triangulasi (cek dan komparasi data dan informasi). Dalam hal ini yang digunakan yaitu Triangulasi sumber. Artinya, satu informasi dari satu sumber dicek/ dibandingkan dengan informasi dari informan lain (buku, makalah, artikel, dan sejenisnya).

Oleh karena penelitian ini merupakan penelitian awal dalam rangka merekonstruksi ilmu pendidikan di lingkungan LPTK, maka analisis data dan informasi yang diperoleh melalui penelusuran dokumen dan wawancara dilakukan secara sederhana. Hal yang dilakukan peneliti yaitu (1) mengidentifikasi nama-nama para tokoh pemikir pendidikan di awal pengembangan LPTK (1954-an hingga akhir 1999-an) yang diperoleh dari penelusuran dokumen dan hasil wawancara dan (2) mengidentifikasi karya-karya bertema pendidikan yang terbit sejak tahun 1954-an hingga akhir 1999-an. Tidak semua nama dan karya yang diperoleh peneliti dapat diidentifikasi asal institusinya, dengan demikian peneliti membuat kalkulasi perkiraan tentatif asal institusi dari para tokoh yang mengkaji ilmu pendidikan. Berdasar data dan informasi tersebut peneliti menyimpulkan sebaran dan dominasi para pemikir ilmu pendidikan dan asal institusinya.

\section{PEMBAHASAN}

Berdasarkan pada jejak sejarah bangsa Indonesia, khususnya sejarah pendidikan, tahun 1950-an hingga 1990-an adalah periode membangun fondasi pendidikan dengan fokus pada infrastruktur dan peningkatan kualitas guru. Sebelumnya, sejak Agustus 1945 hingga akhir 1940-an kondisi pendidikan Indonesia belum stabil. Agresi militer yang dilancarkan oleh militer Belanda di Indonesia sebanyak 2 (dua) kali pasca kekalahan Jepang dan juga berbagai perundingan yang seringkali merugikan bangsa Indonesia, menjadikan upaya membangun sistem pendidikan yang kokoh oleh Ki Hadjar Dewantara dan kawan-kawan kurang berhasil. Baru setelah pengakuan kedaulatan oleh Belanda sejak konferensi Meja Bundar (23 Agustus-2 November 1949, pengakuan kedaulatan baru pada tanggal 27 Desember 1949) Indonesia sedikit demi sedikit mulai dapat menata sistem pendidikannya dengan terlebih dahulu mengesahkan undang-undang pendidikan nasional pada tahun 1950 (Rikclefs, 2005, hlm. 450-466; Mestoko et al., 1986, hlm. 142-168).

Oleh karena itu, begitu kondisi keamanan nasional mulai stabil, pemerintah mengawali upaya meningkatkan 
kualitas pendidikan bagi rakyat Indonesia. Salah satu hal yang dilakukan adalah mengubah beberapa jenis pendidikan guru yang ada waktu itu menjadi pendidikan guru setingkat perguruan tinggi dengan nama Perguruan Tinggi Pendidikan Guru (PTPG) oleh Departemen Pendidikan, Pengajaran, dan Kebudayaan (PPK) pada tahun 1954. Tiap PTPG di Ibu Kota Provinsi kemudian dimasukkan sebagai bagian dari perguruan tinggi setempat dengan status menjadi fakultas, yakni Fakultas Keguruan dan Ilmu Pendidikn (FKIP) pada 1957. FKIP kemudian dilebur dengan Institut Pendidikan Guru (IPG) yang dibentuk oleh Menteri Koordinator Pendidikan, Prof. Priyono (1960) dalam bentuk lembaga baru yang diberi nama Institut Keguruan dan Ilmu Pendidikan (IKIP) pada 1963 oleh Presiden Soekarno (Buchori, 2009, hlm. 82-83).

Upaya peningkatan kualitas lembaga pendidikan calon guru tersebut tetap berlangsung di tengah pergolakan pergantian rezim dari Presiden Soekarno ke Presiden Soeharto. Banyak dana digelontorkan pemerintah untuk meningkatkan kualitas guru dan LPTK. Di masa inilah kebutuhan untuk mengembangkan bahan ajar dan sumber belajar yang memadai bagi mahasiswa calon guru dan para guru pada umumnya meningkat. Termasuk kebutuhan menyediakan referensi mengenai ilmu pendidikan atau pedagogik di LPTK. Pada periode ini banyak akademisi di LPTK dilibatkan oleh Departemen Pendidikan dan Kebudayaan (Depdikbud) maupun Direktorat Jenderal Pendidikan Tinggi (Ditjend Dikti) untuk menulis referensi-referensi mengenai pendidikan, termasuk ilmu pendidikan. Dengan demikian dapat disimpulkan bahwa tahun 1950-an adalah masa membangun fondasi keilmuan, khususnya ilmu pendidikan di LPTK dilihat dari diterbitkannya banyak buku-buku ilmu pendidikan oleh pada pemikir pendidikan dari LPTK.

Buchori (2009) menyebut masa itu sebagai masa ekspansi dan modernisasi LPTK yang dalam banyak kasus menjadikan beberapa tokoh pendidikan tak hanya menetap dalam satu institusi saja. Melainkan sering dipindahtugaskan ke LPTK lain maupun lembaga non LPTK. Beberapa tokoh yang masuk dalam kategori ini antara lain Mochtar Buchori, Setijadi, dan Soegarda Poerbakawatja. Buchori pernah menjadi bagian dari IKIP Ban-dung, Universitas Indonesia (UI), Lembaga Ilmu Pengetahuan Indonesia (LIPI), dan IKIP Muhammadiyah, Ja $\neg$ karta. Setijadi sebelum pindah ke Universitas Terbuka (UT) pernah mengajar di IKIP Jakarta. Poerbakawatja setelah menjadi Kepala Djawatan Pengadjaran Inspektur Djenderal Kementerian PPK kemudian diberi amanat menjadi Rektor Universitas Tjenderawasih, Irian Jaya (Papua). Di antara ketiga tokoh pendidikan tersebut, Buchori cukup intensif dalam mengkaji ilmu pendidikan. Beberapa karyanya antara lain Spektrum Problematika Pendidikan di Indonesia (1994) dan Ilmu Pendidikan dan Praktek Pendidikan (1994). Menurut informan penelitian ini, karya-karya Mochtar Buchori tersebut dan juga yang lainnya masih dijadikan sebagai bahan ajar dan diskusi ilmu pendidikan di berbagai LPTK hingga akhir tahun 1990-an.

Lebih lanjut, gambaran umum mengenai produktivitas para pemikir pendidikan dalam menulis referensi bertema ilmu pendidikan pada kurun waktu 1954-1999 dapat dilihat dari sebaran institusi asal penulis. Selain itu menarik kiranya mengidentifikasi dominasi para pemikir ilmu pendidikan pada waktu itu yang mewarnai wacana ilmu pendidikan di LPTK. Mereka itulah yang dianggap memiliki otoritas dalam ilmu pendidikan dan oleh karenanya dijadikan rujukan atau tempat bertanya mengenai ilmu pendidikan oleh banyak pihak. Bahasan berikut akan mengulas sebaran, keberadaan, dan dominasi para pemikir ilmu pendidikan pada beberapa LPTK.

Dalam jumlah yang lebih banyak para pemikir ilmu pendidikan justru berasal dari IKIP Bandung. Beberapa nama yang melegenda antara lain Sikun Pribadi, Redya Mudyahardja, Kartini Kartono, Ngalim Purwanto, Uyoh Sadulloh, Waini Rasyidin, M.I. Soelaeman, Ag. Soejono, Liem Tjong Tiat, Burhanuddin Salam, dan E. Suardi. Sikun Pribadi misalnya menulis Peranan Filsafat Pendidikan (1970, 1971), Peranan Ilmu Mendidik untuk Pendidikan Profesi Keguruan (1975), Landasan Pendidikan (sebagai editor, 1980), dan Landasanlandasan Kependidikan (sebagai editor 1984). Ia bahkan menulis disertasi mengenai pemikiran pedagogi fenomenologi yang banyak memengaruhi wacana ilmu pendidikan di LPTK sejak tahun 1950-an hingga 1990an akhir, M.J. Langeveld (1965). Berikutnya, Redya Mudyahardja menulis Pengantar Pendidikan (1998), bersama Waini Rasyidin juga menulis Materi Pokok Dasar-dasar Kependidikan dan Kebudayaan (1985, 1986). Hingga tahun 2017 karya-karya Mudyahardja dan Rasyidin masih dicetak ulang dan dijadikan bahan ajar ilmu pendidikan di banyak tempat. Demikian juga dengan beberapa karya Ngalim Purwanto dan Uyoh Sadulloh.

Berikutnya, Kartini Kartono menulis Pengantar Ilmu Mendidik Teoretis: Apakah Pendidikan Masih Diperlukan (1992). Ngalim Purwanto menulis Diktat Pengantar Filsafat Pendidikan (1969), Landasan Epistemologis Pendidikan dan Pengajaran (1972), Ilmu Pendidikan (1987), Ilmu Pendidikan Teoretis dan Praktis (1997), terbit ulang tahun 2004, dan Rekonstruksi Filsafat Pendidikan Nasional (1999). Uyoh Sadulloh 
HISTORIA: Jurnal Pendidik dan Peneliti Sejarah, 3(1), 1-10, DOI: 10.17509/historia.v3i1.17107.

menulis buku bersama Oong Komar berjudul DasarDasar Pendidikan (1985). M.I. Soelaeman menulis Penghampiran Fenomenologis terhadap Pendidikan (1977)-yang dipengaruhi pemikiran-pemikiran pendidikan dari Langeveld, Menjadi Guru (1985), dan Suatu Telaah tentang Manusia-Religi-Pendidikan (1988). Ag. Soejono menulis Pendahuluan Pendidikan Umum (1980), Aliran Baru dalam Pendidikan dan Pengajaran (1958), dan Aliran Baru dalam Pendidikan (1978). Burhanuddin Salam menulis Pengantar Pedagogik (1996, 1997), E. Suardi menulis Pedagogik 1, 2, dan 3 (1984), Liem Tjong Tiat menulis Diktat Pengantar Pedagogik Sistematis (1963) dan Filsafat Pendidikan dan Pedagogik (1969).

Setelah IKIP Bandung, IKIP Yogyakarta dapat dikatakan mememiliki para pemikir besar ilmu pendidikan yang mendominasi wacana ilmu pendidikan di LPTK sejak 1950-an hingga 1990-an akhir. Dua nama besar dari IKIP Yogyakarta yaitu Noeng Muhadjir dan Imam Barnadib. Muhadjir misalnya menulis buku ilmu pendidikan yang dicetak dengan revisi berkali-kali, dari tahun 1964, 1970, 1977, 1987, 1993 (edisi IV) dengan judul Ilmu Pendidikan dan Perubahan Sosial: Suatu Teori Pendidikan. Terdapat beberapa kali perubahan judul dari terbitan pertama hingga keempat. Barnadib menulis Filsafat Pendidikan (1965), Dasar-dasar Pendidikan Perbandingan (1974), Sistem-sistem Filsafat Pendidikan (1975), Tujuan Pendidikan Nasional (1976), Filsafat Pendidikan: Pengantar Mengenai Sistem dan Metode (1976), Filsafat Pendidikan (1982), Pemikiran tentang Pendidikan Baru (1983), Pengantar Ilmu Pendidikan Sistematis (1986, 1989), Pendidikan Perbandingan buku 1 dan 2 (1987), Ke Arah Perspektif Baru Pendidikan (1988), Filsafat Pendidikan: Sistem dan Metode (1990), dan Dasar-dasar Kependidikan: Memahami Makna dan Perspektif Beberapa Teori Pendidikan (1996).

Selain Muhadjir dan Barnadib, beberapa pemikir yang menulis tentang ilmu pendidikan lainnya dari IKIP Yogyakarta di antaranya adalah Suparlan, Sumitro, Notonagoro, S. Bradjanaro, Dirto Hadi Susanto, dan Wisnu Giyono. Suparlan misalnya menulis Aliranaliran Baru dalam Pendidikan (1984), Sumitro menulis Pengantar Ilmu Pendidikan (1989), Notonagoro menulis Filsafat Pendidikan Nasional Pancasila (1973), Bradjanaro menulis Ilmu Pendidikan (1962), Susanto menulis bersama penulis lain buku berjudul Pengantar Ilmu Pendidikan (1995), dan Giyono menulis Ilmu Pendidikan (1996). Selain itu juga ada Siti Meichati yang menyadur buku Crow \& Crow berjudul Pengantar Ilmu Pendidikan. Buku ini naik cetak hingga terbitan ketiga tahun 1994 (edisi 1 terbit tahun 1950-an, edisi 2 tahun 1967, edisi 3 cetakan pertama terbit tahun
1988, cetakan kedua tahun 1990, dan cetakan ketiga 1994). St. Vembriarto juga penulis produktif dari IKIP Yogyakarta sejak masa IKIP Yogyakarta masih bagian dari Universitas Gadjah Mada (UGM). Namun ia tidak secara khusus menulis mengenai ilmu pendidikan. Beberapa penulis produktif mengenai pendidikan dari IKIP Yogyakarta tersebut mulanya berasal dari UGM sebagai perguruan tinggi induk. Beberapa ikut menjadi bagian IKIP Yogyakarta, lainnya tetap di UGM namun juga berkontribusi menulis ilmu pendidikan, misalnya Notonagoro.

Beberapa IKIP lain dapat dikatakan tidak terlalu produktif dalam menulis karya-karya bertema ilmu pendidikan. Di IKIP Jakarta misalnya ada 2 (dua) nama yang dalam kurun waktu 1954-1999 pernah mengulas ilmu pendidikan, yaitu Winarno Surahkmad dan Connie Semiawan. Surakhmad misalnya menulis Ilmu Pendidikan untuk Pembangunan yang dimuat di majalah Prisma (1986). Beberapa karyanya yang lain tidak secara khusus mengambil topik ilmu pendidikan, namun tetap terkait dengan ilmu pendidikan, di antaranya Manusia Indonesia Seutuhnya: Adakah Persepsi Kependidikan Masa Depan (1986), Faktor-faktor Sosial Budaya dalam Hubungannya dengan Pendidikan Guru (1969/1970), dan Dasar dan Teknik Interaksi Mengajar dan Belajar (1973). Sementara itu Connie Semiawan antara lain menulis Hakikat Pendidikan di Sekolah Dasar (1990, 1991), Pendekatan Keterampilan Proses: Bagaimana Mengaktifkan Siswa dalam Belajar (1988, 1992), Mencari Strategi Pengembangan Pendidikan Nasional Menjelang Abad XXI (sebagai editor bersama Soedijarto, 1991), dan Pendidikan Tinggi: Peningkatan Kemampuan Manusia Sepanjang Hayat Seoptimal Mungkin (1999).

Selain Surakhmad dan Semiawan, beberapa nama lain dari IKIP Jakarta seperti Soedijarto, Setijadi, H.A.R. Tilaar, Moleong, dan Poedjawijatna juga merupakan para pemikir besar. Hanya saja sejauh penelusuran peneliti, mereka tidak secara khusus menulis mengenai ilmu pendidikan dalam kurun waktu 1954-1999. Soedijarto misalnya banyak menulis mengenai kurikulum dan sistem pendidikan nasional. Setijadi sejauh penelusuran peneliti dianggap sebagai tokoh yang cukup progresif dalam memandang praktik pendidikan, hanya saja jejak dokumen gagasannya relatif minim. H.A.R. Tilaar pada periode itu banyak aktif di birokrasi pemerintah dan baru menulis mengenai ilmu pendidikan sejak awal 2000-an hingga sekarang (Subkhan, 2017). Sementara itu Moleong lebih dikenal sebagai pakar metodologi penelitian dan Peodjawijatna sebagai pakar filsafat dengan bukunya yang terkenal Pembimbing ke Arah Alam Filsafat (1980) yang ditujukan terutama untuk para mahasiswa IKIP. Hal menarik yang perlu 
didiskusikan berkaitan dengan fenomena ini adalah: apa yang mengebabkan IKIP Jakarta tidak memiliki banyak pemikir ilmu pendidikan-yang betul-betul mendalam menulis tema ilmu pendidikan-dalam periode 1954 hingga 1990? Sejauh ini peneliti belum memperoleh alasan dan jawabannya yang pasti dan memuaskan.

Berikutnya, di IKIP Malang terdapat T. Raka Joni yang banyak terlibat proyek pengembangan kualitas guru dan LPTK di Depdikbud dan Ditjend Dikti. Namanya kondang di kalangan LPTK hingga akhir tahun 1990-an. Ia menulis Wawasan Kependidikan (1981) dan Wawasan Kependidikan Guru (1984). Ada juga M. Noor Syam yang menerbitkan buku saduran berjudul Pengantar Filsafat Pendidikan (1973). Wayan Ardhana juga tercapat pernah menjadi editor buku berjudul Dasar-Dasar Kependidikan (1971). Di IKIP Malang sebenarnya terdapat tokoh pendidikan dasar yang diakui secara nasional, yakni Supartinah Pakasi, hanya saja fokusnya memang pada pendidikan dasar. Sejauh ini peneliti belum menemukan tulisannya yang khusus membahas ilmu pendidikan. Berikutnya, di IKIP Surabaya terdapat Made Pidarta yang cukup produktif menulis. Di antaranya ia bersama kawan-kawan menulis buku hasil penelitian berjudul Usaha Menemukan Konsep-Konsep Baru tentang Ilmu Pendidikan (1991), Landasan Kependidikan: Stimulus Ilmu Pendidikan Bercorak Indonesia (1977, 1997, 2013), dan Perencanaan Pendidikan Partisipatoris dengan Pendekatan Sistem (1990). Di IKIP Ujung Pandang terdapat Umar Tirtarahardja dan La Sula. Tirtarahardja menulis buku berjudul Dasar-Dasar Kependidikan (1990). Ia bersama La Sula juga menulis Pengantar Pendidikan (1994).

Di IKIP Padang sejauh penelusuran peneliti terdapat nama tenar Zahara Idris dan Lisma Jamal. Keduanya menulis buku Pengantar Pendidikan I dan II (1992). Sebelumnya Zahara Idris menulis Dasar-dasar kependidikan (1981). Sementara itu di IKIP Semarang terdapat nama Satmoko, Retno Sriningsih Satmoko (istri Satmoko, Satmoko dan Retno Sriningsih Satmoko adalah pasangan suami istri yang mengajar hingga awal tahun 2000-an, dari IKIP Semarang hingga berubah menjadi Universitas Negeri Semarang), Waridjan, dan Soetinah Soewondo. Hanya saja penelusuran peneliti hanya menemukan data karya Retno Sriningsih Satmoko dan Soetinah Soewondo. Retno Sriningsih Satmoko menulis Pengantar Pendidikan (t.t.) dan Landasan Kependidikan: Pengantar ke Arah Ilmu Pendidikan Pancasila (1999), sedangkan Soetinah Soewondo menulis Dasar-Dasar Pendidikan (1993). Peneliti belum dapat menemukan karya yang khusus tentang ilmu pendidikan dari Satmoko dan Waridjan. Namun memang berdasarkan penuturan beberapa informan, mereka berdua adalah tokoh pemulia ilmu pendidikan di IKIP Semarang pada waktu itu. Lebih lanjut, dari IKIP Sura-karta muncul nama Abu Ahmadi yang menulis Pendidikan dari Masa ke Masa (1987) dan bersama Nur Uhbiyati menulis Ilmu Pendidikan $(1991,2001)$. Karyanya masih dicetak ulang dan dinikmati oleh para mahasiswa LPTK hingga sekarang.

Melihat pada produktivitas dalam menulis tema ilmu pendidikan dan asal institusi para penulis sebagaimana telah diulas sebelumnya, dapat dikatakan bahwa memang LPTK di pulau Jawa masih mendominasi. Jika ditelusuri dari perspektif sejarah, memang tahun 1950 hingga 1990-an adalah masa transisi dari kemerdekaan ke pembangunan. Oleh karena itu wajar jika LPTK yang maju relatif terdapat di pulau Jawa. Hal ini dikuatkan dengan orientasi pembangunan masa Orde Baru yang fokus di pulau Jawa sebagai pusat kekuasaan. Hingga akhir 1990-an tampak dominasi tersebut belum luntur. Jika menyebutkan nama, setidaknya terdapat beberapa yang sering disebut sebagai tokoh pendidikan yang juga menulis tema ilmu pendidikan sejak tahun 1950 hingga 1990-an, yaitu Imam Barnadib, Noeng Muhadjir, Sikun Pribadi, Kartini Kartono, Redja Mudyahardja, Ngalim Purwanto, Waini Rasyidin, Raka Joni, Mochtar Buchori, dan Made Pidarta. Kecuali Mochtar Buchori yang berpindah-pindah tempat mengajar, semua nama yang disebut relatif menetap tempat mengajarnya.

Penelusuran peneliti juga menemukan bahwa karya-karya mengenai ilmu pendidikan yang mengambil judul pedagogik, ilmu pendidikan, landasan pendidikan, dan sejenisnya juga diterbitkan oleh Depdikbud dan Ditjen Dikti. Peneliti menemukan beberapa terbitan yang mengatasnamakan tim dari Depdikbud. Termasuk terdapat beberapa nama yang familiar dapat diketahui dari LPTK tertentu. Beberapa nama penulis lain belum dapat peneliti identifikasi asal institusi dan perannya dalam penulisan buku tersebut sebagai apa. Misalnya buku berjudul Ilmu Pendidikan jilid I dan II (1973) yang diatasnamakan tim Depdikbud, namun terdapat nama I.P. Simandjuntak. Terdapat juga buku berjudul Paedagogik dan Pendidikan Nasional $(1976,1986)$ yang ditulis oleh tim dari Depdikbud dan juga Dasar-dasar Kependidikan (1987). Ditjend Dikti juga menerbitkan buku Dasar Ilmu Pendidikan (1981) untuk materi dasar program Akta Mengajar.

Beberapa penulis yang dapat peneliti identifikasi antara lain Dimyati yang menulis buku berjudul Landasan Kependidikan: Suatu Pengantar Pemikiran Keilmuan tentang Kegiatan Pendidikan (1988), Sutan Santi Arbi menulis Pengantar kepada Filsafat Pendidikan (1988), dan Sutan Santi Arbi bersama kawan-kawan menulis Dasar-Dasar Pendidikan (1991, 1992). Banyaknya 
HISTORIA: Jurnal Pendidik dan Peneliti Sejarah, 3(1), 1-10, DOI: 10.17509/historia.v3i1.17107.

terbitan dari Depdikbud dan Ditjend Dikti, termasuk terbitan yang lahir disokong oleh proyek penulisan buku kependidikan besar-besaran, baik yang ditulis secara mandiri maupun menerjemahkan dan menyadur, menunjukkan peran besar dari Depdikbud, Ditjend Dikti, dan para penulis produktif ilmu pendidikan dalam membangun dasar keilmuan di lingkungan LPTK. Secara khusus bahkan patut ditelaah lebih lanjut mengenai diskursus keilmuan di lingkungan Depdikbud dan Ditjend Dikti berkaitan dengan wacana pendidikan secara umum. Adakah dinamika pemikiran ilmu pendidikan di lingkungan Depdikbud dan Ditjend Dikti, termasuk di kalangan akademisi yang terlibat dalam beberapa proyek peningkatan kualitas guru, dosen, dan LPTK pada waktu itu.

Di sisi lain, peneliti juga mengidentifikasi beberapa terbitan dan penulis ilmu pendidikan yang belum dapat peneliti asal institusinya. Entah dari LPTK, atau perguruan tinggi umum, atau apakah terbitan tersebut disokong oleh pemerintah atau tidak. Beberapa nama yang muncul misalnya A. Gazali, I. Jassin, Abd. Manan, Moh. Mubangid Ronoandojo, dan S. Nasution sebagai tim yang menulis Didaktik Umum, Pengantar Pedagogik, Aliran-aliran Baru Pendidikan. Beberapa buku tersebut diterbitkan oleh penerbit Ganaco, Bandung. Sayang peneliti belum memperoleh data lengkap beberapa terbitan, termasuk tahun terbitnya. Peneliti menduga beberapa penulis tersebut berasal dari IKIP Bandung, karena da nama S. Nasution yang produktif menulis mengenai kurikulum berasal dari IKIP Bandung dan penerbit Ganaco yang berada di Bandung. Dengan demikian, selain buku-buku proyek yang didanai dan diterbitkan oleh Depdikbud, Ditjend Dikti, dan penerbitpenerbit internal LPTK seperti IKIP Yogyakarta Press, IKIP Semarang Press, IKIP Bandung Press dan lainnya, penerbit-penerbit swasta juga punya peran besar dalam menerbitkan dan menyebarkan gagasan-gagasan ilmu pendidikan ke mahasiswa-khususnya mahasiswa LPTK_dan masyarakat awam pada umumnya.

Hampir semua karya yang ditulis oleh para pemikir ilmu pendidikan tersebut berwujud buku dengan berbagai variannya, antara lain diktat dan bahan ajar. Hanya beberapa yang berwujud tulisan di majalah. Hal tersebut karena memang yang dituju dan yang disasar adalah peningkatan kualitas guru, mahasiswa calon guru, dan para akademik di LPTK, oleh karenanya tepat ditulis dalam bentuk buku. Waktu itu juga belum banyak jurnal ilmiah yang diterbitkan dan dikelola oleh LPTK, walau sebenarnya riset-riset keilmuan dalam bidang ilmu pendidikan juga sudah dirintis. Oleh karenanya relatif sulit dilacak hasil-hasil riset bertema ilmu pendidikan yang diterbitkan oleh jurnal ilmiah oleh para pemikir ilmu pendidikan tersebut. Ulasan mengenai ilmu pendidikan beberapa kali muncul juga di majalah popular maupun semi ilmiah bertema pendidikan yang dikelola oleh pemerintah maupun swasta (majalah Prisma misalnya). Teks-teks lain dalam bentuk pidato pengukuhan guru besar, makalah semi $\neg$ nar atau konferensi, artikel opini di media massa. Beberapa makalah dan artikel opini di media massa juga dibukukan hingga lebih menarik dibaca oleh publik, misalnya karya-karya Mochtar Buchori.

\section{SIMPULAN}

Berdasarkan bahasan sebelumnya dapat disimpulkan bahwa keberadaan para tokoh pemikir ilmu pendidikan di tahun 1950-an hingga 1990-an belum merata. Sebagian besar berada di Jawa, khususnya di Bandung, Yogyakarta, Jakarta, kemudian Ma $\neg$ lang, Surabaya, dan Semarang. Jika dilihat dari sisi kekuatan wacana yang digaungkan dan sisi ketokohan, tampak IKIP Yogyakarta dan IKIP Bandung sangat dominan, baru kemudian IKIP Malang, IKIP Jakarta dan lainnya. Di kancah nasional nama-nama seperti Imam Barnadib, Noeng Muhadjir, Redja Mudyahardja, Raka Joni, Ngalim Purwanto, Kartini Kartono, Sikun Pribadi, Made Pidarta, dapat dikatakan sebagai para pionir yang serius mengkaji ilmu pendidikan dan produktif mempublikasikannya. Jangkauan publikasinya pun tampak cukup luas dan bahkan beberapa di antaranya tetap digunakan sebagai referensi mengenai ilmu pendidikan hingga sekarang. Fakta ini menunjukkan dua kemungkinan, antara rendahnya minat mengkaji dan menulis (produktivitas) tema ilmu pendidikan para akademisi pendidikan saat ini atau memang karena karya mereka memang bersifat lintas zaman. Penelitian ini memang baru fokus pada sebaran dan dominasi para pemikir ilmu pendidikan. Berkaitan dengan substansi keilmuan, coraknya, dan juga perkembangannya hendaknya perlu diteliti lebih mendalam lagi.

\section{REFERENSI}

Ahmadi, A. (1987). Pendidikan dari masa ke masa. Bandung: Armico.

Ahmadi, A. dan Uhbiyati, N. (1991). Ilmu pendidikan. Jakarta; Rineka Cipta.

Arbi, S.S. (1988). Pengantar kepada filsafat pendidikan. Jakarta: DItjen Dikti, Depdikbud.

Arbi, S.S. dan Syahrun, S. (1991/1992). Dasar-dasar kependidikan. Jakarta: P2TK, Ditjen Dikti, Depdikbud.

Ardhana, W. (ed.) (1971). Dasar-dasar kependidikan. Malang: FIP IKIP. 
Barnadib, I. (1965). Filsafat pendidikan. Yogyakarta: Adi Cipta Karya Nusa.

Barnadib, I. (1974). Dasar-dasar pendidikan perbandingan. Yogyakarta: Insitute Press IKIP Yogyakarta.

Barnadib, I. (1975). Sistem-sistem filsafat pendidikan. Yogyakarta: Yayasan Penerbitan FIP IKIP.

Barnadib, I. (1976). Filsafat pendidikan: pengantar mengenai sistem dan metode. Yogyakarta; Yayasan Penerbitan FIP IKIP Yogyakarta.

Barnadib, I. (1976). Tujuan pendidikan nasional. Yogyakarta: Perpustakaan Pusat IKIP Yogyakarta.

Barnadib, I. (1982). Filsafat pendidikan. Yogyakarta: Yayasan Penerbit FIP IKIP Yogyakarta.

Barnadib, I. (1983). Pemikiran tentang pendidikan baru. Yogyakarta: Andi Offset.

Barnadib, I. (1986, 1989). Pengantar ilmu pendidikan Sistematis. Yogyakarta: FIP IKIP Yogyakarta

Barnadib, I. (1987). Pendidikan perbandingan. Buku dua. Persekolahan dan perkembangan masyarakat. Yogyakarta: Andi Offset.

Barnadib, I. (1987). Pendidikan perbandingan. Buku satu. Dasar-dasar. Yogyakarta: Andi Offset.

Barnadib, I. (1988). Ke arah perspektif baru pendidikan. Jakarta: Ditjen Dikti, Depdikbud.

Barnadib, I. (1990). Filsafat pendidikan: Sistem dan metode. Yogyakarta: Andi Offset.

Barnadib, I. (1996). Dasar-dasar kependidikan: memahami makna dan perspektif beberapa teori pendidikan. Jakarta: Ghalia Indonesia.

Bradjanaro, S. (1962). Ilmu pendidikan. Yogyakarta: Fakultas Phaedagogiek UGM.

Buchori, M. (1994). Ilmu pendidikan dan praktek pendidikan. Jakarta: IKIP Muhammadiyah Jakarta Press.

Buchori, M. (1994). Spektrum problematika pendidikan di indonesia. Yogyakarta: Tiara Wacana.

Buchori, M. (2009). Evolusi pendidikan di indonesia: dari kweekschool sampai ke ikip: 1852-1998. Yogyakarta: Insist Press.

Departemen Pendidikan dan Kebudayaan. (1976/1986). Pedagogik dan pendidikan nasional. Jakarta: Proyek Pengadaan Buku SPG.

Depertemen Pendidikan dan Kebudayaan. (1973). Ilmu pendidikan jilid i. prof. i.p. Simanjuntak. Proyek Pengadaan Buku SPG.

Depertemen Pendidikan dan Kebudayaan. (1973). Ilmu pendidikan jilid ii. Prof. I.P. Simanjuntak. Proyek Pengadaan Buku SPG.

Depertemen Pendidikan dan Kebudayaan. (1987). Dasar-dasar kependidikan. Bandung: IKIP Bandung.
Dimyati, M. (1988). Landasan kependidikan.: suatu pengantar pemikiran keilmuan tentang kegiatan pendidikan. Jakarta: proyek pengembangan lembaga pendidikan tenaga kependidikan, Ditjen Dikti, Depdkbud.

Direktorat Jenderal Pendidikan Tinggi. (1981). Dasar ilmu pendidikan. materi dasar akta mengajar $v$. buku IIA. Jakarta: Proyek PIPT Ditjen Dikti, Depdikbud.

Fridiyanto. (2013). Tan malaka guru revolusioner: penggagas pendidikan kritis. Yogyakarta: Gre Publsihing.

Giyono, W. (1996). Ilmu pendidikan. Yogyakarta: Penerbit Swadaya.

Herlinawati, D. (2007). Konsep pendidikan multikultural h.a.r. tilaar: relevansinya dengan pendidikan islam. Skripsi: UIN Sunan Kalijogo, tidak diterbitkan.

Idris, Z. (1981). Dasar-dasar kependidikan. Bandung: Penerbit Angkasa.

Idris, Z. dan Jamal, L. (1992). Pengantar pendidikan $i$. Jakarta: Grasindo.

Idris, Z. dan Jamal, L. (1992). Pengantar pendidikan ii. Jakarta: Grasindo.

Joni, T.R. (1981). Wawasan kependidikan. Jakarta: Depdikbud.

Joni, T.R. (1984). Wawasan kependidikan guru. Jakarta: PPLPTK.

Joyo, F. (2013). Pemikiran pendidikan kritis prof. h.a.r. tilaar dan relevansinya dalam pendidikan islam. Skripsi: UIN Sunan Kalijogo, tidak diterbitkan.

Kahfi, M.A. (2013). Hubungan antara kekuasaan dengan pendidikan agama islam: rekonstruksi pemikiran h.a.r. tilaar tentang kekuasaan dan pendidikan. Skripsi: UIN Sunan Kalijogo, tidak diterbitkan.

Kartono, K. (1992). Pengantar ilmu mendidik teoretis: apakah pendidikan masih diperlukan? Bandung: Mandar Maju.

Meichati, S. (1967). Pengantar ilmu pendidikan. Saduran. Yogyakarta: Yayasan Penerbit. FIP IKIP Yogyakarta.

Mestoko, S., Bachtiar, S., Sunityo, dam Arif, A. (1986). Pendidikan di indonesia dari Jaman ke Jaman. Jakarta: Balai Pustaka.

Mudyahardja, R. dan Rasyidin, W. (1986). Dasar-dasar kependidikan. Jakarta: UT, Depdikbud.

Mudyahardjo, R. (2001). Filsafat ilmu pendidikan: suatu pengantar. Bandung: Remaja Rosdakarya.

Mudyahardjo, R. (2014). Pengantar pendidikan: sebuah studi awal tentang dasar-dasar pendidikan pada umumnya dan pendidikan di indonesia. Jakarta: Rajawali Pers.

Mudyahardo, R. dan Rasyidin, W. (1985, 1986). Materi pokok dasar-dasar kependidikan dan kebudayaan. Universitas Terbuka. Jakarta. 
HISTORIA: Jurnal Pendidik dan Peneliti Sejarah, 3(1), 1-10, DOI: 10.17509/historia.v3i1.17107.

Mudyahardo, R., Rasyidin, W., dan Soegiyanto, S. (1992). Materi pokok dasar-dasar kependidikan. modul 1-6. Jakarta: P2TK-PT, Depdikbud.

Muhadjir, N. (1993). Ilmu pendidikan dan perubahan sosial: suatu teori pendidikan. Edisi IV. Yogyakarta: Rake Sarasin.

Navis, A.A. (1996). Filsafat dan strategi pendidikan $m$. sjafei: ruang pendidikan ins kayutanam. Jakarta: Grasindo.

Notonagoro. (1973). Filsafat pendidikan nasional pancasila. Yogyakarta: FIP IKIP Yogyakarta.

Nugroho, S. (2003). Pendidikan pemerdekaan \& islam: refleksi pemikiran yb. mangunwijaya. Yogyakarta: Pondok Edukasi.

Pidarta, I.M. (1990). Perencanaan pendidikan partisipatoris dengan pendekatan sistem. Jakarta: Rineka Cipta.

Pidarta, I.M. (1997). Landasan kependidikan: stimulus ilmu pendidikan bercorak indonesia. Jakarta: Rineka Cipta.

Pidarta, I.M. et al. (1991). Usaha menemukan konsepkonsep baru tentang ilmupendidikan. hasilpenelitian. Surabaya: Pusat Penelitian IKIP Surabaya.

Poedjawijatna, I.R. (1980). pembimbing ke arah alam filsafat. Jakarta: PT. Pembangunan.

Pribadi, S. (1965). In search of a formulation of the general aim of education. Ohio State University.

Pribadi, S. (1970,1971). Peranan filsafat pendidikan. Bandung: FIP IKIP.

Pribadi, S. (1975). Peranan ilmu mendidik untuk pendidikan profesi keguruan. Bandung: Jurusan FIlsafat Pendidikan FIP IKIP Bandung.

Pribadi, S. (ed.) (1984). Landasan-landasan kependidikan. Bandung: FIP IKIP/UPI.

Pribadi, S. (Ed.). (1980). Landasan pendidikan. Bandung: FIP IKIP.

Purbakawatja, S. (1970). Pendidikan dalam alam indonesia merdeka. Jakarta: Gunung Agung.

Purwanto, N. (1969). Diktatpengantar filsafatpendidikan. Bandung: FIP IKIP Bandung.

Purwanto, N. (1972). Landasan epistemologis pendidikan dan pengajaran. Bandung: Jurusan FFP/FIP IKIP Bandung (tidak diterbitkan)

Purwanto, N. (1987). Ilmu pendidikan. Jakarta: Remadja Karya.

Purwanto, N. (1997, 2004). Ilmu pendidikan teoretis dan praktis. Bandung: Remaja Rosdakarya.

Purwanto, N. (1999). Rekonstruksi filsafat pendidikan nasional. Dalam jurnal FAKTA. Lampung: FKIP Universitas Ratu Inten, Bandar Lampung.
Riklefs, M.C. (2005). Sejarah indonesia modern: 12002004. Terj. Satrio Bawono dkk. Jakarta: Serambi.

Sadulloh, U. \& Komar, O. (1985). Dasar-dasarpendidikan. Bandung: FIP IKIP Bandung.

Salam, B.H. (1996, 1997). Pengantar pedagogik: dasardasar ilmu mendidik. Bandung: Rineka Cipta.

Satmoko, R.S. (tt.). Pengantar pendidikan. Jakarta: Universitas Terbuka.

Satmoko, R.S. (1999). Landasan kependidikan: pengantar ke arah ilmu pendidikan pancasila. Semarang: IKIP Semarang Press.

Semiawan, C. $(1990,1991)$. Hakikat pendidikan di sekolah Dasar. Makalah disajikan dalam penataran calon penatar dalam rangka persiapan penyelenggaraan program DII PGSD, P2TK, Ditjen Dikti, Depdikbud, Juni-Agustus 1990, Bogor.

Semiawan, C. (1999). Pendidikan tinggi: peningkatan kemampuan manusia sepanjang hayat seoptimal mungkin. Jakarta: Ditjen Dikti, Depdikbud.

Semiawan, C. dan Soedijarto. (eds.). (1991). Mencari strategi pengembangan pendidikan nasional menjelang abad xxi. Jakarta: Grasindo.

Semiawan, C. et al. (1988, 1992). Pendekatan keterampilan prosees: bagaimana mengaktifkan siswa dalam belajar. Jakarta: Gramedia.

Soejono, A. (1958). Aliran baru dalam pendidikan dan pengajaran. Jakarta: Mutiara.

Soejono, A. (1978). Aliran baru dalam pendidikan. Bandung: CV. Ilmu.

Soejono, A. (1980). Pendahuluan pendidikan umum. Bandung: Bina Ilmu.

Soelaeman, M.I. (1977). Penghampiran fenomenologis terhadap pendidikan. Bandung: IKIP Bandung.

Soelaeman, M.I. (1985). Menjadi guru. Bandung: IKIP Bandung.

Soelaeman, M.I. (1988). Suatu telaah tentang manusiareligi-pendidikan. Jakarta: Direktorat Pendidikan Tinggi, Depdikbud.

Soeratman, D. (1986). Ki hadjar dewantara. Jakarta: Depdikbud.

Soewondo, S. (1993). Dasar-dasar pendidikan. Semarang: Effhar Publishing.

Suardi, E. (1984). Pedagogik 1, 2, 3. Bandung: Angkasa.

Subkhan, E. (2017). Merintis Ilmu Pendidikan Berfilosofi Pancasila yang Memerdekakan. Dalam M. Marbawi dan J. Phaat (eds), Tinjauan secara kritis reformasi pendidikan nasional. Jakarta: Media Indonesia Publishing, pp. 103-130.

Sumitro. (1989). Pengantar ilmu pendidikan. Yogyakarta: Purbo. 
Suparlan. (1984). Aliran-aliran baru dalam pendidikan. Yogyakarta: Andi Offest.

Supriadi, D. (ed.) (2003). Guru di indonesia: pendidikan, pelatihan dan perjuangannya sejak zaman kolonial hingga era reformasi. Jakarta: Departemen Pendidikan Nasional Republik Indonesia.

Surakhmad, W. (1969/1970). Faktor-faktor sosial budaya dalam hubungannya dengan pendidikan guru. Jakarta: Proyek rehabilitasi pendidikan guru.

Surakhmad, W. (1973). Dasar dan teknik interaksi mengajar dan belajar. Bandung: Tarsito.

Surakhmad, W. (1986). Ilmu pendidikan untuk pembangunan: sebuah kebutuhan strategik dunia ketiga. Jakarta: majalah Prisma.

Surakhmad, W. (1986). Manusia indonesia seutuhnya: adakah persepsi kependidikan masa depan. Jakarta: IKIP Jakarta.

Susanto, D.H. et al. (1995). Pengantar ilmu pendidikan. Yogyakarta: FIP IKIP Yogya $\neg$ karta.
Suwignyo, A. (2012). The breach in the dike: regime change and the standardization of public primaryschool teacher training in indonesia (1893-1969). Leiden: disertasi.

Syam, M.N. (1973). Pengantar filsafat pendidikan. saduran. Malang: IKIP Malang.

Tiat, L.T. (1963). Diktat pengantar pedagogik sistematis. Bandung: Jurusan Ilmu Mendidik FKIP-Unpad.

Tiat, L.T. (1969). Filsafat pendidikan dan pedagogik. Bandung: FIP IKIP Bandung.

Tirtarahardja, U. (1990). Dasar-dasar kependidikan. Ujung Pandang: FIP IKIP.

Tirtarahardja, U. dan Sula, La. (1994). Pengantar pendidikan. Jakarta: Rineka Cipta.

Wirojoedo, S. (1985). Teori perencanaan pendidikan. Yogyakarta: Liberti.

Zaini, A. (2011). K.h.a. wahid hasyim: pembaru pendidikan islam dan pejuang kemerdekaan. Jombang: Pustaka Tebu Ireng. 